\title{
SPEECH ACTS IN BARACK OBAMA SPEECH'S \\ IN ANNOUNCING THE DEATH OF OSAMA BIN LADEN
}

\author{
Atiya Mahmud Hana \\ Universitas Nahdlatul Ulama Yogyakarta \\ atiya@unu-jogja.ac.id
}

\begin{abstract}
This study aims to observe and describe the use of speech acts by Barack Obama when he announced the death of Osama bin Laden. The writer focuses on illocutionary acts used by Barack Obama. The primary data source is the transcript of Barack Obama's speech at White House on May $1^{\text {st }}, 2011$ after the death of Osama bin Laden. The types of illocutionary acts are observed by the writer according to Searle's Taxonomy of Illocutionary Act. They are representatives, directives, commissives, expressives, and declarations. The result of the study shows that representatives are frequetnly used by Obama in his speech. Representatives are used in 54 utterances (74\%); Commissives are used in 11 utterances (15\%); Expressives are used in 7 utterances (11\%). Barack Obama used none both directive speech acts and declaration speech acts. Representatives are frequently used in Barack Obama speech because the purpose of the speech is to announce the death of Osama bin Laden in Pakistan. The evidence is that most utterances in the transcipt use statements, descriptions, and reports.
\end{abstract}

Keywords: speech act, illocutionary acts, Barack Obama

\section{INTRODUCTION}

Spoken language is different from written language. In spoken language, people produce an utterance as an action. It means that they can do anything through utterances for certain purposes such as reporting, promising, offering, congratulating, requesting, commanding, asserting apologizing, thanking. To express the idea, people do not only produce utterances consisting grammatical structure, but also they do an action with their utterances.

Based on the Austin theory in Mey (1993: 112), an utterance has three types of acts. They are locutionary, illocutionary, and perlucotionary. Locutionary aspect has to do with 'the utterance of a sentence with determinate sense and reference'; illocutionary aspect with 'naming of a statement, offer, promise, etc., in uttering a sentence, by virtue of the conventional force associated with it'; whereas the perlocutionary aspect deals with 'the bringing about of effects on the audience by 
means of uttering the sentence, such effects being special to the circumstances of utterances.'

As we know, Barack Obama was the president of America. He was elected twice of presidential election in America. On May 1, 2011, he made a great speech at White House in announcing the death of Osama bin Laden. In the writer point of view, it is interesting to observe and describe the speech acts especially from illocutionary act used by Obama in his speech.

The writer of this study intends to observe and describe the use of speech acts by Barack Obama when he announced the death of Osama bin Laden. This study focuses on illocutionary acts used by Barack Obama. The writer used Searle classification of illocutionary acts that include representatives, directives, commisives, expressives, and declarations.

\section{LITERATURE REVIEW}

\section{Speech Acts}

Speech acts are a part of Pragmatics. According to Yule (1996: 47), speech acts are defined as actions performed via utterances. These utterances are commonly given more specific labels such as apology, complaint, compliment, invitation, promise, or request. In speech acts theory, utterances have two kinds of meaning termed as propositional (locutionary) meaning and illocutionary meaning (force).

The concept of illocutionary acts was introduced by J. L. Austin in his investigation of the various aspects of speech acts. According to Austin (1975), locution is what was said, illocution is what was meant, and perlocution is what happened as a result. When somebody says "Is there any salt?" at the dinner table, the illocutionary act (the meaning) is effectively "please give me some salt" even though the locutionary act (the literal sentence) was to ask a question about the presence of salt.

Austin's theory in Thomas (1995: 49) made three-fold distinction of speech act. They are locution, illocution, and perlocution. Locution means the words uttered. Illocution means the force or intention behind the words. Perlocution means the effect of the illocution on the hearer. For instance, I might say: It's hot in here! (locution), meaning: I want some fresh air! (illocution) and the perlocutionary effect might be that someone opens the window.

There are some experts that made a classification of illocutionary acts. Classification of illocutionary acts based on Searle (1975) are assertives, directives, commisives, expressives, and declarations.

1. Assertives

Assetives mean speech acts that commit a speaker to the truth of the expressed proposition 
2. Directives

Directives mean speech acts that are to cause the hearer to take a particular action, e.g. requests, commands and advice

3. Commissives

Commisives mean speech acts that commit a speaker to some future action, e.g. promises and oaths

4. Expressives

Expressives mean speech acts that express on the speaker's attitudes and emotions towards the proposition, e.g. congratulations, excuses and thanks

5. Declarations

Declarations mean speech acts that change the reality in accord with the proposition of the declaration, e.g. baptisms, pronouncing someone guilty or pronouncing someone husband and wife

Some years later, Searle in Mey (1993: 131) divides the illocutionary acts into representatives, directives, commisives, expressives, and declarations. The following are the explanation of each:

1. Representatives

The point of which is to represent a state of affairs; which have a word-toworld fit, i.e. the intention is to make the words fit the world; in which a belief is expressed; and in which any proposition can occur.

The examples of representatives are statement, assertion, claim, description, hypothesis, conclusion, report, suggestion, and prediction.

2. Directives

The point of which is to direct the hearer towards doing something; which have a world-to-word direction of fot; in which a wish is expressed; in which the proposition is a future act done by the hearer.

The examples of directives are ordering, questioning, commanding, requesting, inviting, etc.

3. Commissives

The point of which is that the speaker commits himself to doing something; which have a world-to-word direction of fit; in which an intention is expressed; in which the proposition is a future act done by the speaker.

The examples of commissives are promising, threatening, offering, guarantineeing, vowing, warning, berring, challenging, etc.

4. Expressives

The point of which is that a certain psychological state is expressed; which have no direction of fit; in which the proposition ascribes a property or act to the speaker or the hearer.

The examples of expressives are congratulating, apologizing, thanking, appreciating, complaining, etc.

5. Declarations

The point of which is to bring something about in the world; which have both a word-to-world and a world-to-word direction of fit; in which no psychological state is expressed; in which any proposition can occur. 
The examples of declarations are excommunication, baptizing, arresting, marrying, etc.

In this study, the writer analysed the transcript by using Searle classification in 1993 that include representatives, directives, commisives, expressives, and declarations. Each utterance given by Barack Obama when he announced the death Osama bin Laden was classified based on that classification.

\section{Previous Studies}

A research related to the topic was done by Ubong E. Josiah and Sifonde Effiong Johnson from Department of English, University of Uyo Uyo, Akwa Iborn State, Nigeria. They conducted a research entitled 'Pragmatic Analyses of President Goodluck Jonathan's and President Barack Obama's Inaugural Addresses'. Its purpose investigates the first inaugural addresses of two presidents: Nigeria's Goodluck Ebela Jonathan (2011) and America's Barrack Obama (2009).

The research focuses on speech act theory. It considers the illocutionary forces in the speeches as well as the face-threatening and face-saving acts respectively, with the aim of identifying the similarities and differences in the speech. The result shows that the speeches are relatively alike because each speaker speaks for his entire nation, regardless of his political party, and both speeches show a preponderance of 'representative' and 'commisives'. However, while President Jonathan's commisives show predominance in the use of modal verbs to express intention. President Obama's commisives consist of modal verbs and infinitive clauses to project volition and intention.

Another research was conducted by M. Tholhah Al Hadi entitled 'An Analysis of Speech Acts Found in Barack Obama's Speech in University of Indonesia'. The purpose of his study is to investigate Barack Obama's speech when he was in University of Indonesia, November 10th, 2010.

The result of the study shows that speech acts used by Barack Obama can be described as follows: first, the researcher does not find declarative one. As well as conflictive which is one of the function of speech act (illocutionary act), declarative is not found because the context of the utterances being conducted by Barack Obama in University of Indonesia is not to bring about the change in the world even though the purpose of the speech is in the opposite.

In addition, the utterances of Obama are mostly in the form of assertive (representative) which means committing the speaker to the truth of expressed proposition. The following ranks belong to directive, expressive, and then commisive because there is nothing for declarative. At the same time, the functions of the utterances mostly belong to collaborative. While the following positions belong to competitive, and then convivial. 


\section{RESEARCH METHOD}

The object of the study is a discourse particularly utterances in the form of orthographic transcription. The data is Barack Obama speech when he announced the death of Osama bin Laden on May 1, 2011. The source of the data is from CBS News. The data is collected through direct observation looking at very carefully to use the language. The method of data analysis is observing the speech acts used by Barack Obama in his speech focused on illocutionary speech acts. Then the data is presented descriptively and interpretatively.

The primary data source of this study is the transcript of a speech given by Barack Obama when he announced the death of Osama bin Laden. The transcipt was downloaded from CBS News (http://www.cbsnews.com/news/full-text-ofobamas-speech-on-bin-ladens-death/). Beside the transcript, the reseacher downloaded the video from https://www.youtube.com/watch?v=ZNYmK19-d0U to see directly when Barack Obama delivered the speech. To support the primary data, the writer reads some books and articles which have relationship to the topic.

In collecting the data, the writer divided into three steps. Firstly, the writer did collecting the primary data and the secondary data from some sources and books related to the topic. Secondly, he classified the data according to speech acts theory of illocutionary acts that include representatives, directives, commissives, expressives, and declarations. The last step was the writer interpreted the data based on the transcript qualitatively.

\section{FINDINGS AND DISCUSSIONS}

After analyzing the data, the writer found 73 utterances from Barack Obama's speech in announcing the death of Osama bin Laden. The table below shows the findings of illocutionary acts from the transcript:

\begin{tabular}{|c|c|c|}
\hline Illocutionary Acts & Utterances & Percentage \\
\hline Representatives & 54 & $74 \%$ \\
\hline Directives & 0 & $0 \%$ \\
\hline Commissives & 11 & $15 \%$ \\
\hline Expressives & 8 & $11 \%$ \\
\hline Declarations & 0 & $0 \%$ \\
\hline Total & $\mathbf{7 3}$ & $\mathbf{1 0 0 \%}$ \\
\hline
\end{tabular}

The table clearly shows that representatives are frequently used in Obama's speech. There are 54 utterances (74\%). Representatives mean Barack Obama 
represent a state of affairs. Most representatives found in the speech are statements, descriptions, and reports. The following are the examples of statements from the transcript:

(38) I've made clear, just as President Bush did shortly after 9/11, that our war is not against Islam.

(39) Bin Laden was not a Muslim leader; he was a mass murderer of Muslims.

(40) Indeed, al Qaeda has slaughtered scores of Muslims in many countries, including our own.

Statements are used by Obama to represent the American people point of view after the death of Osama bin Laden. They are happy because the justice has been done after the death of Osama bin Laden in Pakistan. The next finding is about description. The following are the examples of descriptions found in the transcipt.

(3) It was nearly 10 years ago that a bright September day was darkened by the worst attack on the American people in our history.

(4) The images of $9 / 11$ are seared into our national memory -hijacked planes cutting through a cloudless September sky; the Twin Towers collapsing to the ground; black smoke billowing up from the Pentagon; the wreckage of Flight 93 in Shanksville, Pennsylvania, where the actions of heroic citizens saved even more heartbreak and destruction.

(5) In Afghanistan, we removed the Taliban government, which had given bin Laden and al Qaeda safe haven and support.

Descriptions above are given by Obama to tell American people and people around the world about the cronological events in the operation to kill Osama bin Laden in Pakistan. The next type of representative speech act found is report. Report is almost the same as statement. The following is the example:

(2) Tonight, I can report to the American people and to the world that the United States has conducted an operation that killed Osama bin Laden, the leader of al Qaeda, and a terrorist who's responsible for the murder of thousands of innocent men, women, and children.

The table above also shows that commissive speech acts are found in 11 utterances (15\%). Most commisive speech acts found in the transcript are offering and warning. Offering given by Barack Obama can be seen in utterance 10 below.

(10) We offered our neighbors a hand, and we offered the wounded our blood. 
Barack Obama did not use 'I' in his utterance. He used 'we' because he wanted to show the unity of American people. Besides offering, warning is also found in the transcript. The following are the example of threatening found in utterance 34,42 and 54.

(34) Yet his death does not mark the end of our effort.

(42) Over the years, I've repeatedly made clear that we would take action within Pakistan if we knew where bin Laden was.

(54) Yet as a country, we will never tolerate our security being threatened, nor stand idly by when our people have been killed.

Commissive speech acts found in the transcript mean Barack Obama as the President of America and American people commit to act in the way represented by the propositional way content. It is represented the use of offering and warning used by Barack Obama in his transcript speech.

The next finding is expressive speech act. Expressive speech acts show that Barack Obama expressed the sincerity and condition of illocutionary act. There are eight utterances represented expressive speech acts in the transcipt. They are greeting and thanking. Greeting is found in the first utterance. The following is the greeting found in the transcript:

\section{(1) Good evening.}

Greeting above shows that the speech was given in evening. Barack Obama used the greeting in beginning of speech to express his sincerity. Besides greeting, thanking is also found in the transcript. The following are the examples of thanking given by Barack Obam in his speech.

(16) Over the last 10 years, thanks to the tireless and heroic work of our military and our counterterrorism professionals, we've made great strides in that effort.

(58) Tonight, we give thanks to the countless intelligence and counterterrorism professionals who've worked tirelessly to achieve this outcome.

(61) We give thanks for the men who carried out this operation, for they exemplify the professionalism, patriotism, and unparalleled courage of those who serve our country.

In giving gratitude, Barack Obama again used 'we' to represent himself as the President of America and American people. He gave special thanks to a small team of Americans carried out the operation to kill Osama bin Laden in Pakistan.

Based on the data above, Barack Obama used representatives in 54 utterances (74\%), commissives in 11 utterances (15\%), and expressives in 7 utterances $(11 \%)$. The writer did not find any directive and declaration speech acts in the 
transcript. Speech usually do not use both directive and declaration. Both of them might be found in form of dialogue.

\section{CONCLUSION}

The writer can conclude that representative speech acts are frequently used in Barack Obama's speech in announcing the death of Barack Obama. Representatives are used in 54 utterances (74\%); Commissives are used in 11 utterances (15\%); Expressives are used in 7 utterances (11\%). Barack Obama used none both directive speech acts and declaration speech acts. Representatives are frequently used in Barack Obama speech because the purpose of the speech is to announce the death of Osama bin Laden in Pakistan. The evidence is that most utterances in the trancript use statements, descriptions, and reports.

\section{REFERENCES}

Austin, John L. 1975. How To Do Things with Words. Oxford: Oxford University Press.

Josiah, Ubong E. and Sifonde Effiong Johnson. 2012. Pragmatic Analyses of President Goodluck Jonathan's and President Barack Obama's Inaugural Addresses. International Journal of Humanities and Social Science. Vol 2 No. 12.

Mey, Jacob. L. 1993. Pragmatics: an Introduction. Oxford: Blackwell Publishers.

Searle, John R. 1975. "A Taxonomy of Illocutionary Acts”, in: Günderson, K. (ed.), Language, Mind, and Knowledge, Minneapolis, vol. 7.

Thohlah, M Al Hadi. 2011. An Analysis of Speech Acts in Barack Obama's Speech in University of Indonesia. State Islamic University of Malang. Final Project.

Thomas, Jenny. 1995. Meaning in Interaction: an Introduction to Pragmatics. New York: Addison Wesley Longman Publishing.

Yule, G. 1996. Pragmatics - Introduction to Language Study. Oxford: Oxford University Press.

\section{Writer Biography}

Atiya Mahmud Hana is a lecturer at Nahdlatul Ulama Univeristy of Yogyakarta, Indonesia. He teaches at English Department focusing on teaching Grammar and Educational Research. He has conducted some research related to English teaching and Linguistics. 


\section{APPENDIX:}

\section{The Transcript of Barack Obama's Speech}

\section{http://www.cbsnews.com/news/full-text-of-obamas-speech-on-bin-ladens-death/}

President Barack Obama speaks from the White House after the death of Osama bin Laden on May 1, 2011. CBS News

The president announced to the nation that "justice has been done" in the death of Osama bin Laden. A small team of Americans carried out the operation to kill bin Laden in Pakistan.

(1) Good evening.

(2) Tonight, I can report to the American people and to the world that the United States has conducted an operation that killed Osama bin Laden, the leader of al Qaeda, and a terrorist who's responsible for the murder of thousands of innocent men, women, and children.

(3) It was nearly 10 years ago that a bright September day was darkened by the worst attack on the American people in our history.

(4) The images of 9/11 are seared into our national memory -- hijacked planes cutting through a cloudless September sky; the Twin Towers collapsing to the ground; black smoke billowing up from the Pentagon; the wreckage of Flight 93 in Shanksville, Pennsylvania, where the actions of heroic citizens saved even more heartbreak and destruction.

(5) And yet we know that the worst images are those that were unseen to the world. The empty seat at the dinner table.

(6) Children who were forced to grow up without their mother or their father.

(7) Parents who would never know the feeling of their child's embrace.

(8) Nearly 3,000 citizens taken from us, leaving a gaping hole in our hearts.

(9) On September 11, 2001, in our time of grief, the American people came together.

(10) We offered our neighbors a hand, and we offered the wounded our blood.

(11) We reaffirmed our ties to each other, and our love of community and country.

(12) On that day, no matter where we came from, what God we prayed to, or what race or ethnicity we were, we were united as one American family.

(13) We were also united in our resolve to protect our nation and to bring those who committed this vicious attack to justice.

(14) We quickly learned that the 9/11 attacks were carried out by al Qaeda -- an organization headed by Osama bin Laden, which had openly declared war on the United States and was committed to killing innocents in our country and around the globe.

(15) And so we went to war against al Qaeda to protect our citizens, our friends, and our allies.

(16) Over the last 10 years, thanks to the tireless and heroic work of our military and our counterterrorism professionals, we've made great strides in that effort. 
(17) We've disrupted terrorist attacks and strengthened our homeland defense.

(18) In Afghanistan, we removed the Taliban government, which had given bin Laden and al Qaeda safe haven and support.

(19) And around the globe, we worked with our friends and allies to capture or kill scores of al Qaeda terrorists, including several who were a part of the 9/11 plot.

(20) Yet Osama bin Laden avoided capture and escaped across the Afghan border into Pakistan.

(21) Meanwhile, al Qaeda continued to operate from along that border and operate through its affiliates across the world.

(22) And so shortly after taking office, I directed Leon Panetta, the director of the CIA, to make the killing or capture of bin Laden the top priority of our war against al Qaeda, even as we continued our broader efforts to disrupt, dismantle, and defeat his network.

(23) Then, last August, after years of painstaking work by our intelligence community, I was briefed on a possible lead to bin Laden.

(24) It was far from certain, and it took many months to run this thread to ground.

(25) I met repeatedly with my national security team as we developed more information about the possibility that we had located bin Laden hiding within a compound deep inside of Pakistan.

(26) And finally, last week, I determined that we had enough intelligence to take action, and authorized an operation to get Osama bin Laden and bring him to justice.

(27) Today, at my direction, the United States launched a targeted operation against that compound in Abbottabad, Pakistan.

(28) A small team of Americans carried out the operation with extraordinary courage and capability.

(29) No Americans were harmed.

(30) They took care to avoid civilian casualties.

(31) After a firefight, they killed Osama bin Laden and took custody of his body.

(32) For over two decades, bin Laden has been al Qaeda's leader and symbol, and has continued to plot attacks against our country and our friends and allies.

(33) The death of bin Laden marks the most significant achievement to date in our nation's effort to defeat al Qaeda.

(34) Yet his death does not mark the end of our effort.

(35) There's no doubt that al Qaeda will continue to pursue attacks against us.

(36) We must -- and we will -- remain vigilant at home and abroad.

(37) As we do, we must also reaffirm that the United States is not -- and never will be -- at war with Islam.

(38) I've made clear, just as President Bush did shortly after 9/11, that our war is not against Islam.

(39) Bin Laden was not a Muslim leader; he was a mass murderer of Muslims.

(40) Indeed, al Qaeda has slaughtered scores of Muslims in many countries, including our own.

(41) So his demise should be welcomed by all who believe in peace and human dignity. 
(42) Over the years, I've repeatedly made clear that we would take action within Pakistan if we knew where bin Laden was.

(43) That is what we've done.

(44) But it's important to note that our counterterrorism cooperation with Pakistan helped lead us to bin Laden and the compound where he was hiding.

(45) Indeed, bin Laden had declared war against Pakistan as well, and ordered attacks against the Pakistani people.

(46) Tonight, I called President Zardari, and my team has also spoken with their Pakistani counterparts.

(47) They agree that this is a good and historic day for both of our nations.

(48) And going forward, it is essential that Pakistan continue to join us in the fight against al Qaeda and its affiliates.

(49) The American people did not choose this fight.

(50) It came to our shores, and started with the senseless slaughter of our citizens.

(51) After nearly 10 years of service, struggle, and sacrifice, we know well the costs of war.

(52) These efforts weigh on me every time I, as Commander-in-Chief, have to sign a letter to a family that has lost a loved one, or look into the eyes of a service member who's been gravely wounded.

(53) So Americans understand the costs of war.

(54) Yet as a country, we will never tolerate our security being threatened, nor stand idly by when our people have been killed.

(55) We will be relentless in defense of our citizens and our friends and allies.

(56) We will be true to the values that make us who we are.

(57) And on nights like this one, we can say to those families who have lost loved ones to al Qaeda's terror: Justice has been done.

(58) Tonight, we give thanks to the countless intelligence and counterterrorism professionals who've worked tirelessly to achieve this outcome.

(59) The American people do not see their work, nor know their names.

(60) But tonight, they feel the satisfaction of their work and the result of their pursuit of justice.

(61) We give thanks for the men who carried out this operation, for they exemplify the professionalism, patriotism, and unparalleled courage of those who serve our country.

(62) And they are part of a generation that has borne the heaviest share of the burden since that September day.

(63) Finally, let me say to the families who lost loved ones on 9/11 that we have never forgotten your loss, nor wavered in our commitment to see that we do whatever it takes to prevent another attack on our shores.

(64) And tonight, let us think back to the sense of unity that prevailed on 9/11.

(65) I know that it has, at times, frayed.

(66) Yet today's achievement is a testament to the greatness of our country and the determination of the American people.

(67) The cause of securing our country is not complete.

(68) But tonight, we are once again reminded that America can do whatever we set our mind to. 
(69) That is the story of our history, whether it's the pursuit of prosperity for our people, or the struggle for equality for all our citizens; our commitment to stand up for our values abroad, and our sacrifices to make the world a safer place.

(70) Let us remember that we can do these things not just because of wealth or power, but because of who we are: one nation, under God, indivisible, with liberty and justice for all.

(71) Thank you.

(72) May God bless you.

(73) And may God bless the United States of America. 